\title{
An Investigation of Comprehensive Income and Firm Performance: The Case of the Electric Appliances Industry of the Tokyo Stock Exchange
}

\author{
Chikashi Tsuji ${ }^{1}$ \\ ${ }^{1}$ Faculty of Economics, Chuo University, 742-1 Higashinakano Hachioji-shi, Tokyo 192-0393, Japan
}

Correspondence: Chikashi Tsuji, Faculty of Economics, Chuo University, 742-1 Higashinakano Hachioji-shi, Tokyo 192-0393, Japan. Tel: 81-42-674-2211. E-mail: mail_sec_low@minos.ocn.ne.jp

Received: March 23, 2013

Accepted: April 8, 2013

Online Published: April 15, 2013

doi:10.5430/afr.v2n2p29

URL: http://dx.doi.org/10.5430/afr.v2n2p29

\begin{abstract}
This study investigates whether comprehensive income is associated with the future performance of the electric appliances industry firms in Japan. We find that regarding the Japanese electric appliances industry firms, comprehensive income is superior to other earnings or cash flow variables in predicting their future stock returns. We consider that our result in this paper provides useful evidence not only for the Japanese but also for the international academicians and practitioners.
\end{abstract}

Keywords: Comprehensive income, Firm performance, International Financial Reporting Standards, Japanese electric appliances industry, Panel data analysis

\section{Introduction}

Many firms started to publish comprehensive income data recently in Japan. How is then comprehensive income informative for investors in capital markets in Japan? In the international researches, there exist some papers which studied on the usefulness of comprehensive income in other markets than in Japan. For example, Biddle and Choi (2006) revealed that comprehensive income defined by Financial Accounting Standards Board (FASB) Statement 130 dominated both traditional net income and fully comprehensive income in explaining equity returns in the US. Further, Chambers et al. (2007) provided the evidence in the post-Statement of Financial Accounting Standards (SFAS) 130 periods that other comprehensive income was priced in the US markets. In addition, Dhaliwal et al. (1999) found no evidence that comprehensive income was more strongly associated with returns in the US. Moreover, Kanagaretnam et al. (2009) found that aggregate comprehensive income was more strongly associated with both stock price and returns compared to net income in Canada. However, as far as we know, there seem to be little research regarding this matter by using the Japanese data.

Based on these backgrounds, therefore, the objective of this study is to examine whether comprehensive incomes, which are published by the Japanese firms in accordance with the International Financial Reporting Standards (IFRS), are informative for judging the future firm performance in the Tokyo Stock Exchange (TSE) electric appliances industry. We note that this industry may be the most representative at the TSE in Japan. This industry includes such firms as Sony Corporation, Panasonic Corporation, Hitachi, Ltd. Toshiba Corporation, and Mitsubishi Electric Corporation, which may be well-known companies in overseas as well.

Our contribution in this paper is as follows: we find that in this Japanese industry, comprehensive income is superior to other earnings or cash flow variables in explaining the future firm performance. The rest of this paper is organized as follows. Section 2 conducts the literature review, Section 3 explains our data set and methodology, section 4 documents the empirical results, and Section 5 concludes the paper.

\section{Literature Review}

This section performs the literature review. The informativeness and usefulness of comprehensive income are well discussed in several well-known existing studies, such as Kiger and Williams (1977), Robinson (1991) and Brief and Peasnell (1996). These are notable and important traditional papers for considering the usefulness of comprehensive income. As Kanagaretnam et al. (2009) suggest, measuring and forecasting future firm performance by using accounting variables are highly important for accounting policy makers and accounting information users. How is 
then comprehensive income useful in the international capital markets? Not so many but several empirical studies exist both for the US and other international markets as follows.

In the previous empirical studies, the results on the usefulness of comprehensive income are mixed. First, Dhaliwal et al. (1999) found that comprehensive income was not more strongly related with stock returns or market value in the US. In addition, the findings of Dhaliwal et al. (1999) indicated that comprehensive income was not a better predictor of future cash flows or income than net income in the US. On the other hand, Biddle and Choi (2006) suggested that broader definitions of income were more informative for investment decision making, and they concluded that the disclosure of comprehensive income components was useful in the US. Furthermore, Chambers et al. (2007) studied by focusing on the post-SFAS 130 adoption period and they found that other comprehensive income was informative and useful in the US. Moreover, Kanagaretnam et al. (2009) found the stronger evidence: they found that aggregate comprehensive income was more strongly associated with both stock prices and returns compared to net income in Canada.

Further, unclear empirical results are also provided regarding the usefulness of other comprehensive income for other international markets. Namely, O'Hanlon and Pope (1999) found little evidence that other flows excluded from ordinary profit were value-relevant for UK firms. In addition, using the data of the New Zealand firms, Cahan et al. (2000) found that although the aggregate amount of comprehensive income had information value, individual components did not.

As above our literature review indicates, it is difficult to draw clear expectations on the relations between future firms' performances and their comprehensive incomes. In addition, it is also difficult to set the specific hypothesis on the linkages between future firms' performances and their comprehensive incomes. Therefore, in this paper, using the data of the TSE electric appliances industry firms, we empirically test whether IFRS comprehensive income predicts the future firm performances in Japan.

\section{Data and Methodology}

We use the data for the fiscal year of 2009 to 2011, and this is because the comprehensive income data published by firms are well available from the fiscal year of 2009 in Japan. Further, in our analyses, we employ the pooled regressions (panel data regression analyses) as we document later. In the regressions, dependent variable is the Japanese firm's six-month future return from the end of the fiscal year of each firm. Firms' future stock returns are used to measure the future performances of the TSE electric appliances industry firms.

As to the explanatory variables, OPP denotes the operating profit to total asset ratio, ORP denotes the ordinary profit to total asset ratio, and EBIT denotes the earnings before interest and tax to total asset ratio. Further, EBITDA denotes the earnings before interest, tax, depreciation and amortization to total asset ratio, OPCASH denotes the operating cash flow to total asset ratio, NI denotes the net income to total asset ratio, and COMP denotes the comprehensive income to total asset ratio. By using these variables, we can compare the usefulness of several accounting variables in predicting future firm performances. Again, we note that our comprehensive income data are the real data published by the Japanese firms and these data are reported in accordance with IFRS.

Moreover, we employ four control variables in our regressions: LNSIZE denotes the log natural of market capitalization, WCP denotes the working capital to total asset ratio, DEBT denotes the total debt to total asset ratio, and TANG denotes the tangible fixed asset to total asset ratio. These variables are typical and general for controlling the firm characteristics in stock return regression analyses. We construct all variables from the data supplied by the Quick Corp.

Next are the models for our panel data analyses. We use three kinds of models, and the first is the single accounting variable model with control variables as following model (1):

$$
R E T_{i, t+6 m}=\delta_{0}+\delta_{1} X_{i, t}+\delta_{2} L N S I Z E_{i, t}+\delta_{3} W C P_{i, t}+\delta_{4} D E B T_{i, t}+\delta_{5} T A N G_{i, t}+\mu_{i, t+6 m} .
$$

Where $X_{i, t}$ is the accounting variable at time $t$, OPP, ORP, EBIT, EBITDA, OPCASH, NI, or COMP. By checking the adjusted $R$-squared values from the regression (1), we understand which accounting variable has the stronger predictable power for future stock returns.

Further, our second model is designed to compare the explanatory power of comprehensive income and other earnings or cash flow variables for the future returns without control variables:

$$
R E T_{i, t+6 m}=\kappa_{0}+\kappa_{1} X_{i, t}+\kappa_{2} \operatorname{COMP} P_{i, t}+\omega_{i, t+6 m} .
$$

Where $X_{i, t}$ is the explanatory variable other than COMP. Namely, $X_{i, t}$ is the variable of OPP, ORP, EBIT, EBITDA, OPCASH, or NI. 
Finally, we set the following model (3) to compare the explanatory power of comprehensive income and other accounting variables for the future equity returns with control variables:

$$
R E T_{i, t+6 m}=\psi_{0}+\psi_{1} X_{i, t}+\psi_{2} \operatorname{COMP}_{i, t}+\psi_{3} \operatorname{LNSIZE}_{i, t}+\psi_{4} \text { WCP }_{i, t}+\psi_{5} D E B T_{i, t}+\psi_{6} T_{A N G_{i, t}}+\kappa_{i, t+6 m}
$$

Where $X_{i, t}$ is the accounting variable other than COMP as in regression (2). In this regression, if COMP dominates the variable, $X_{i, t}$, comprehensive income is superior to other accounting variables in predicting the future firm performances.

Table 1. Descriptive statistics of the analyzed variables as to the Japanese electric appliances industry firms: Balanced panel data for the fiscal year from 2009 to 2011

\begin{tabular}{lcccccc}
\hline \hline & RET & OPP & ORP & EBIT & EBITDA & OPCASH \\
\hline Mean & -18.559 & 4.913 & 4.602 & 4.986 & 10.792 & 8.282 \\
Median & -19.841 & 4.637 & 4.253 & 4.542 & 10.163 & 7.793 \\
Maximum & 47.256 & 25.456 & 25.627 & 26.142 & 36.658 & 30.651 \\
Minimum & -68.046 & -14.312 & -18.267 & -15.359 & -8.014 & -13.966 \\
Standard Deviation & 16.802 & 6.074 & 6.324 & 6.235 & 6.854 & 6.796 \\
Skewness & 0.516 & 0.232 & 0.109 & 0.145 & 0.578 & 0.357 \\
Kurtosis & 4.255 & 3.840 & 4.111 & 3.971 & 3.789 & 3.568 \\
Obs. & 357 & 357 & 357 & 357 & 357 & 357 \\
(Obs. (time-series)) & $(3)$ & $(3)$ & $(3)$ & $(3)$ & $(3)$ & $(3)$ \\
(Obs. (cross-section)) & $(119)$ & $(119)$ & $(119)$ & $(119)$ & $(119)$ & $(119)$ \\
\hline & $\mathrm{NI}$ & $\mathrm{COMP}$ & LNSIZE & WCP & DEBT & TANG \\
\hline Mean & 1.459 & 1.167 & 4.177 & 40.311 & 43.611 & 16.162 \\
Median & 2.136 & 1.834 & 3.831 & 40.464 & 41.771 & 14.521 \\
Maximum & 20.625 & 20.330 & 8.188 & 103.304 & 94.046 & 44.211 \\
Minimum & -34.417 & -33.373 & 1.142 & -20.072 & 1.755 & 0.071 \\
Standard Deviation & 6.568 & 6.679 & 1.621 & 22.370 & 22.003 & 8.500 \\
Skewness & -1.638 & -1.428 & 0.542 & 0.129 & 0.074 & 0.702 \\
Kurtosis & 8.902 & 8.084 & 2.600 & 2.706 & 1.919 & 3.362 \\
Obs. & 357 & 357 & 357 & 357 & 357 & 357 \\
(Obs. (time-series)) & $(3)$ & $(3)$ & $(3)$ & $(3)$ & $(3)$ & $(3)$ \\
(Obs. (cross-section)) & $(119)$ & $(119)$ & $(119)$ & $(119)$ & $(119)$ & $(119)$ \\
\hline \hline Notes: This & & & & \\
& & & & &
\end{tabular}

Notes: This table shows the descriptive statistics for the analyzed variables of the Japanese electric appliances industry firms. These data are balanced panel data from the fiscal year of 2009 to 2011. In the table, RET denotes the six-month future return from the end of the fiscal year of each firm. In addition, OPP denotes the operating profit to total asset ratio, ORP denotes the ordinary profit to total asset ratio, and EBIT denotes the earnings before interest and tax to total asset ratio. Further, EBITDA denotes the earnings before interest, tax, depreciation and amortization to total asset ratio, OPCASH denotes the operating cash flow to total asset ratio, NI denotesthe net income to total asset ratio, and COMP denotes the comprehensive income to total asset ratio. Moreover, LNSIZE denotes the log natural of market capitalization, WCP denotes the working capital to total asset ratio, DEBT denotes the total debt to total asset ratio, and TANG denotes the tangible fixed asset to total asset ratio. Further, Obs. means the number of pooled datafrom the fiscal year of 2009 to 2011. 
Table 2. The relations between profits, cash flows, comprehensive income and six-month future stock returns of the Japanese electric appliances industry firms: The results of the panel data analyses for the fiscal year of 2009 to 2011

\begin{tabular}{|c|c|c|c|c|c|c|c|}
\hline & Model 1 & Model 2 & Model 3 & Model 4 & Model 5 & Model 6 & Model 7 \\
\hline Const. & $-14.275^{* * *}$ & $-14.283 * * *$ & $-14.234 * * *$ & $-15.646 * * *$ & $-15.183 * * *$ & $-13.566 * * *$ & -11.001 \\
\hline$p$-value & 0.000 & 0.000 & 0.000 & 0.000 & 0.000 & 0.000 & 0.000 \\
\hline OPP & $0.534 * * *$ & & & & & & \\
\hline$p$-value & 0.000 & & & & & & \\
\hline ORP & & $0.467 * * *$ & & & & & \\
\hline$p$-value & & 0.000 & & & & & \\
\hline EBIT & & & $0.473 * * *$ & & & & \\
\hline$p$-value & & & 0.000 & & & & \\
\hline EBITDA & & & & $0.201^{* *}$ & & & \\
\hline$p$-value & & & & 0.014 & & & \\
\hline OPCASH & & & & & $0.259 * * *$ & & \\
\hline$p$-value & & & & & 0.004 & & \\
\hline NI & & & & & & $0.352 * * *$ & \\
\hline$p$-value & & & & & & 0.000 & \\
\hline COMP & & & & & & & $0.444 * * *$ \\
\hline$p$-value & & & & & & & 0.000 \\
\hline LNSIZE & $-1.800 * * *$ & $-1.634 * * *$ & $-1.643 * * *$ & $-1.409 * * *$ & $-1.455^{* * *}$ & $-1.302 * * *$ & $-1.401 * * *$ \\
\hline$p$-value & 0.000 & 0.000 & 0.000 & 0.000 & 0.000 & 0.000 & 0.000 \\
\hline WCP & 0.042 & 0.038 & 0.038 & $0.065^{*}$ & $0.074 *$ & 0.042 & 0.019 \\
\hline$p$-value & 0.236 & 0.245 & 0.258 & 0.080 & 0.061 & 0.180 & 0.520 \\
\hline DEBT & -0.038 & -0.036 & -0.041 & -0.044 & -0.051 & -0.051 & $-0.061 *$ \\
\hline$p$-value & 0.293 & 0.291 & 0.254 & 0.238 & 0.206 & 0.112 & 0.055 \\
\hline TANG & 0.024 & 0.014 & 0.013 & -0.008 & -0.022 & 0.013 & -0.035 \\
\hline$p$-value & 0.704 & 0.825 & 0.838 & 0.909 & 0.761 & 0.819 & 0.505 \\
\hline $\operatorname{Adj} . R^{2}$ & 0.168 & 0.157 & 0.149 & 0.108 & 0.133 & 0.186 & 0.210 \\
\hline Obs. & 357 & 357 & 357 & 357 & 357 & 357 & 357 \\
\hline
\end{tabular}

Notes: This table shows the results of the panel data analyses for the fiscal year of 2009 to 2011 . The dependent variable is the Japanese electric appliances industry firm'ssix-month future return from the end of the fiscal year of each firm. With respect to the explanatory variables, OPP denotes the operating profit to total asset ratio, ORP denotes the ordinary profit to total asset ratio, and EBIT denotes the earnings before interest and tax to total asset ratio. Further, EBITDA denotes the earnings before interest, tax, depreciation and amortization to total asset ratio, OPCASH denotes the operating cash flow to total asset ratio, NI denotes net income to total asset ratio, and COMP denotes the comprehensive income to total asset ratio. Moreover, we employ four control variables in regressions: LNSIZE denotes the log natural of market capitalization, WCP denotes the working capital to total asset ratio, DEBT denotes the total debt to total asset ratio, and TANG denotes the tangible fixed asset to total asset ratio. In addition, Const. in this table means the constant term of regressions. Further, Obs. means the number of panel data sample and $A d j . R^{2}$ is the adjusted $R$-squared value. ${ }^{* *}$ denotes the statistical significance of the coefficients at the $1 \%$ level, ** denotes the statistical significance of the coefficients at the $5 \%$ level, and $*$ denotes the statistical significance of the coefficients at the $10 \%$ level, respectively. 
Table 3. The comparisons of the explanatory power for six-month future stock returns of several accounting variables and comprehensive income of the Japanese electric appliances industry firms: The results of the panel data analyses without control variables for the fiscal year of 2009 to 2011

\begin{tabular}{|c|c|c|c|c|c|c|}
\hline & Model 1 & Model 2 & Model 3 & Model 4 & Model 5 & Model 6 \\
\hline Const. & $-20.309 * * *$ & $-20.319 * * *$ & $-20.368 * * *$ & $-17.868 * * *$ & $-19.752 * * *$ & $-19.691 * * *$ \\
\hline$p$-value & 0.000 & 0.000 & 0.000 & 0.000 & 0.000 & 0.000 \\
\hline OPP & 0.096 & & & & & \\
\hline$p$-value & 0.377 & & & & & \\
\hline ORP & & 0.125 & & & & \\
\hline$p$-value & & 0.281 & & & & \\
\hline EBIT & & & 0.114 & & & \\
\hline$p$-value & & & 0.314 & & & \\
\hline EBITDA & & & & $-0.235^{* * *}$ & & \\
\hline$p$-value & & & & 0.004 & & \\
\hline OPCASH & & & & & -0.020 & \\
\hline$p$-value & & & & & 0.765 & \\
\hline NI & & & & & & $-0.970 * * *$ \\
\hline$p$-value & & & & & & 0.000 \\
\hline COMP & $0.417 * * *$ & $0.378 * * *$ & $0.394 * * *$ & $0.612 * * *$ & $0.442 * * *$ & $1.415 * * *$ \\
\hline$p$-value & 0.000 & 0.000 & 0.000 & 0.000 & 0.000 & 0.000 \\
\hline $\operatorname{Adj} . R^{2}$ & 0.110 & 0.118 & 0.118 & 0.102 & 0.134 & 0.185 \\
\hline Obs. & 357 & 357 & 357 & 357 & 357 & 357 \\
\hline
\end{tabular}

Notes: This table shows the results of the panel data analyses for the fiscal year of 2009 to 2011. The dependent variable is the Japanese electric appliances industry firm's six-month future return from the end of the fiscal year of each firm. With respect to the explanatory variables, OPP denotes the operating profit to total asset ratio, ORP denotes the ordinary profit to total asset ratio, and EBIT denotes the earnings before interest and tax to total asset ratio. Further, EBITDA denotes the earnings before interest, tax, depreciation and amortization to total asset ratio, OPCASH denotes the operating cash flow to total asset ratio, NI denotes the net income to total asset ratio, and COMP denotes the comprehensive income to total asset ratio. In addition, Const. in this table means the constant term of regressions. Further, Obs. means the number of panel data sample and $A d j . R^{2}$ is the adjusted $R$-squared value. $* * *$ denotes the statistical significance of the coefficients at the $1 \%$ level, $* *$ denotes the statistical significance of the coefficients at the 5\% level, and * denotes the statistical significance of the coefficients at the $10 \%$ level, respectively.

\section{Empirical Results}

First, we display the descriptive statistics for the analyzed variables of the Japanese electric appliances industry firms in Table 1. These statistics are those of the panel data for the fiscal year from 2009 to 2011. In this table, we can overview the statistic characteristics of our variables employed in this study. The numbers of pooled data are in cross-section, 119, in time-series, 3-years, and 357 panel data. In addition, we exhibit the results of our pooled regression (1) in Table 2, the results of regression (2) in Table 3, and results of regression (3) in Table 4.

Regarding the empirical results, first, Table 2 indicates that from the adjusted $R$-squared values, comprehensive income is the strongest predictor of the future six-month stock returns of the TSE electric appliances industry firms. Second, Table 3 shows that when we implement one-to-one explanatory power comparison between comprehensive incomes and other earnings or cash flow variables, comprehensive incomes always dominate other variables in regression (2). Thirdly, Table 4 demonstrates that even if we include four control variables, LNSIZE, WCP, DEBT, and TANG, results are the same. Namely, the predictable power of comprehensive income for future returns is the strongest and robust in the TSE electric appliances industry. 
Table 4. The comparisons of the explanatory power for six-month future stock returns of several accounting variables and comprehensive income of the Japanese electric appliances industry firms: The results of the panel data analyses with control variables for the fiscal year of 2009 to 2011

\begin{tabular}{|c|c|c|c|c|c|c|}
\hline & Model 1 & Model 2 & Model 3 & Model 4 & Model 5 & Model 6 \\
\hline Const. & $-11.964 * * *$ & $-11.001 * * *$ & $-11.241 * * *$ & $-9.661 * * *$ & $-11.689 * * *$ & $-11.748 * * *$ \\
\hline$p$-value & 0.000 & 0.000 & 0.000 & 0.001 & 0.000 & 0.000 \\
\hline OPP & $0.263^{* *}$ & & & & & \\
\hline$p$-value & 0.040 & & & & & \\
\hline ORP & & 0.146 & & & & \\
\hline$p$-value & & 0.263 & & & & \\
\hline EBIT & & & 0.160 & & & \\
\hline$p$-value & & & 0.211 & & & \\
\hline EBITDA & & & & -0.083 & & \\
\hline$p$-value & & & & 0.308 & & \\
\hline OPCASH & & & & & 0.116 & \\
\hline$p$-value & & & & & 0.147 & \\
\hline NI & & & & & & $-0.770 * * *$ \\
\hline$p$-value & & & & & & 0.001 \\
\hline COMP & $0.325 * * *$ & $0.364 * * *$ & $0.366^{* * *}$ & $0.471 * * *$ & $0.465 * * *$ & $1.162 * * *$ \\
\hline$p$-value & 0.003 & 0.002 & 0.002 & 0.000 & 0.000 & 0.000 \\
\hline LNSIZE & $-1.683 * * *$ & $-1.565^{* * *}$ & $-1.582 * * *$ & $-1.299 * * *$ & $-1.682 * * *$ & $-1.253 * * *$ \\
\hline$p$-value & 0.000 & 0.000 & 0.000 & 0.000 & 0.000 & 0.000 \\
\hline WCP & 0.019 & 0.013 & 0.015 & 0.010 & 0.026 & 0.028 \\
\hline$p$-value & 0.568 & 0.686 & 0.648 & 0.734 & 0.447 & 0.379 \\
\hline DEBT & -0.047 & $-0.057 *$ & $-0.056^{*}$ & $-0.073 * *$ & -0.044 & $-0.058^{*}$ \\
\hline$p$-value & 0.180 & 0.086 & 0.100 & 0.028 & 0.214 & 0.067 \\
\hline TANG & -0.017 & -0.029 & -0.027 & -0.047 & -0.056 & -0.042 \\
\hline$p$-value & 0.778 & 0.620 & 0.640 & 0.383 & 0.351 & 0.485 \\
\hline Adj. $R^{2}$ & 0.187 & 0.189 & 0.183 & 0.215 & 0.178 & 0.221 \\
\hline Obs. & 357 & 357 & 357 & 357 & 357 & 357 \\
\hline
\end{tabular}

Notes: This table shows the results of the panel data analyses for the fiscal year of 2009 to 2011 . These results are one-to-one comparison of the predictable power of comprehensive income and other accounting variables for the future firm performance. The dependent variable is the Japanese electric appliances industry firm's six-month future return from the end of the fiscal year of each firm. With respect to the explanatory variables, OPP denotes the operating profit to total asset ratio, ORP denotes the ordinary profit to total asset ratio, and EBIT denotes the earnings before interest and tax to total asset ratio. Further, EBITDA denotes the earnings before interest, tax, depreciation and amortization to total asset ratio, OPCASH denotes the operating cash flow to total asset ratio, NI denotes the net income to total asset ratio, and COMP denotes the comprehensive income to total asset ratio. Moreover, we employ four control variables in regressions: LNSIZE denotes the log natural of market capitalization, WCP denotes the working capital to total asset ratio, DEBT denotes the total debt to total asset ratio, and TANG denotes the tangible fixed asset to total asset ratio. In addition, Const. in this table means the constant term of regressions. Further, Obs. means the number of panel data sample and $A d j . R^{2}$ is the adjusted $R$-squared value. $* * *$ denotes the statistical significance of the coefficients at the $1 \%$ level, $* *$ denotes the statistical significance of the coefficients at the $5 \%$ level, and * denotes the statistical significance of the coefficients at the $10 \%$ level, respectively. 


\section{Conclusions}

This study investigated the information contents of the IFRS comprehensive income associated with the future performance of the Japanese electric appliances industry firms listed on the TSE. We found that for the Japanese electric appliances industry firms, comprehensive incomes published by the firms were superior to other earnings or cash flow variables in predicting their future stock returns over the fiscal year of 2009 to 2011. This is our most interesting contribution in this paper.

Our interpretation of this evidence is that investors generally look at the bottom line of the profit and loss statements of the TSE electric appliances industry firms. We also consider that more comprehensive investigations including other industries may lead to the stronger conclusions, thus such study shall be one of our future tasks. Further, it is also interesting to conduct similar researches by using international data set and these may be our future works as well.

\section{Acknowledgements}

The author thanks the Japan Society for the Promotion of Science for their generous financial assistance for this research. In addition, the author greatly thanks the kind invitation from the journal to write to this journal. Further, I also thank the Editor and anonymous referees for their constructive comments to this paper.

\section{References}

Biddle, G. C., \& Choi, J. H. (2006). Is comprehensive income useful? Journal of Contemporary Accounting and Economics, 2, 1-32. http://dx.doi.org/10.1016/S1815-5669(10)70015-1

Brief, R. P., \& Peasnell, K. V. (Eds.). (1996). Clean Surplus: A Link Between Accounting and Finance, Garland Publishing, NY.

Cahan, S., Courtenay, S., Gronewoller, P., \& Upton, D. (2000). Value relevance of mandated comprehensive income disclosures. Journal of Business Finance and Accounting, 27, 1233-1265. http://dx.doi.org/10.1111/1468-5957.00356

Chambers, D., Linsmeier, T. J., Shakespeare, C., \& Sougiannis, T. (2007). An evaluation of SFAS No. 130 comprehensive income disclosures. Review of Accounting Studies, 12, 557-593. http://dx.doi.org/10.1007/s11142-007-9043-2

Dhaliwal, D., Subramanyam, K. R., \& Trezevant, R. (1999). Is comprehensive income superior to net income as a measure of firm performance? Journal of Accounting and Economics, 26, 43-67. http://dx.doi.org/10.1016/S0165-4101(98)00033-0

Kanagaretnam, K., Mathieu, R., \& Shehata, M. (2009). Usefulness of comprehensive income reporting in Canada. Journal of Account and Public Policy, 28, 349-365. http://dx.doi.org/10.1016/j.jaccpubpol.2009.06.004

Kiger, J. E., \& Williams, J. R. (1977). An emerging concept of income presentation. The Accounting Historians Journal, 4, 63-77.

O’Hanlon, J. F., \& Pope, P. F. (1999). The value-relevance of UK dirty surplus accounting flows. British Accounting Review, 31, 459-482. http://dx.doi.org/10.1006/bare.1999.0116

Robinson, L. (1991). The time has come to report comprehensive income. Accounting Horizons, 5, $107-112$. 